\title{
The association of infectious mononucleosis and breast cancer in The Health of Women (HOW) Study®
}

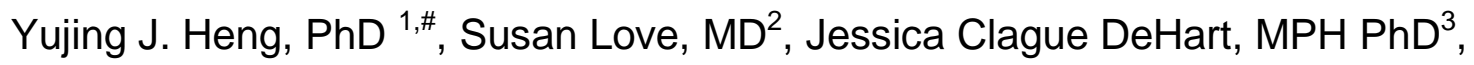
Joyce D. Fingeroth, $\mathrm{MD}^{4}$, Gerburg M. Wulf, MD PhD

1. Department of Pathology, Beth Israel Deaconess Medical Center, Harvard Medical School, Boston, MA, USA

2. Dr. Susan Love Research Foundation, West Hollywood, CA, USA

3. School of Community and Global Health, Claremont Graduate University, Claremont, CA, USA

4. Department of Medicine, University of Massachusetts Medical School, Worcester, MA, USA

5. Department of Medicine, Beth Israel Deaconess Medical Center, Harvard Medical School, Boston, MA, USA

\#Corresponding author: Dr. Jan Heng, Department of Pathology, Beth Israel Deaconess Medical Center, Harvard Medical School, 330 Brookline Ave, Boston, MA 02115, USA; Tel: +1-617-667-4132; Email: yheng@bidmc.harvard.edu

Short running title: Mononucleosis and breast cancer

Keywords: Epstein-Barr virus, breast cancer risk, epidemiology, questionnaires

Data availability: NA

Abstract: $300 / 350$

Words: $2455 / 3000$

Tables+Figures: 3

Supplementary Tables/Figures: None.

References: 40 
medRxiv preprint doi: https://doi.org/10.1101/2021.10.05.21264564; this version posted October 7, 2021. The copyright holder for this preprint (which was not certified by peer review) is the author/funder, who has granted medRxiv a license to display the preprint in perpetuity.

\section{Abstract}

Background. The link between Epstein-Barr Virus (EBV) and breast cancer (BC) remains unclear. Infectious mononucleosis (IM) is a clinical manifestation of delayed onset of EBV infection in early adulthood. We utilized the Health of Women (HOW) Study $\AA$ to understand the association between IM and BC risk.

Subjects and methods. The HOW Study $\AA^{\circ}$ was a web-based survey of BC risk factors with >40,000 participants who answered seven modules between 2012 and 2015; 3,654 women had IM between the ages of 10 and 22 years (16.8\%) and 17,026 never developed IM (78.5\%). Of these 20,680 women, 1,997 (9.7\%) had Stages I-III BC and 13,515 (65.4\%) were cancer-free. Multivariable binary logistic regression ascertained the association between IM and BC risk by controlling for ethnicity, family history, age at menarche, oral contraceptive use, tobacco use, birthplace, parity, age at first birth, body mass index, and breast biopsy. Secondary analyses stratified cancer cases into those who had $B C$ at $<50$ or $\geq 50$ years old and by estrogen receptor (ER) subtype.

Results. Participants were mostly white, middle-aged women born in the United States or Canada. Women who had IM were less likely to develop BC than those who did not develop IM (adjusted odds ratio $(\mathrm{OR})=0.83,95 \%$ confidence interval $(\mathrm{Cl})$ 0.71-0.96). Findings were similar when stratifying women into $<50$ or $\geq 50$ years old at $B C$ diagnosis ( $<50$ years old, adjusted $\mathrm{OR}=0.82,95 \% \mathrm{Cl} 0.67-0.998 ; \geq 50$ years old, adjusted $\mathrm{OR}=0.83,95 \% \mathrm{Cl} 0.69-1.00)$. Women who had IM were less likely to develop ER positive $\mathrm{BC}$ (adjusted $\mathrm{OR}=0.84,95 \% \mathrm{Cl} 0.71-0.997$ ); there was no association between IM and ER negative BC (adjusted $\mathrm{OR}=0.88,95 \% \mathrm{Cl} 0.65-1.16$ ).

Conclusion. In the HOW Study ${ }^{\circledR}$, women diagnosed with IM between the ages of 10 and 22 had lower breast cancer risk compared to women who never developed IM. 
medRxiv preprint doi: https://doi.org/10.1101/2021.10.05.21264564; this version posted October 7, 2021. The copyright holder for this preprint (which was not certified by peer review) is the author/funder, who has granted medRxiv a license to display the preprint in perpetuity. All rights reserved. No reuse allowed without permission.

\section{Introduction}

Over ninety percent of the world's adult population are exposed to Epstein-Barr Virus (EBV) during their childhood [1]. Early life EBV infections typically manifest as subclinical illness whilst delayed onset into early adulthood may manifest as infectious mononucleosis (IM) [2]. EBV infection is an established risk factor in the subsequent development of Hodgkin's lymphoma [3], African Burkitt's lymphoma [4], gastric cancer [5], and nasopharyngeal carcinoma [6]. The ubiquitous nature of EBV infection and its link to cancer has prompted a call for an EBV vaccine $[7,8]$.

In 1995, Labrecque et al. published the first report about EBV in breast tumors [9]. Since then, the majority of research in this area was geared towards detecting and describing the frequency of EBV positive breast tumors [10-19]. Our group [20] and others $[21,22]$ have conducted preclinical in vivo and in vitro studies to understand the mechanisms of EBV in breast cancer cells. Unsurprisingly, the reports regarding the frequencies of EBV positive breast cancer in pathology specimens are inconsistent and may be explained by differences in geography and laboratory methods used to detect this herpesvirus-polymerase chain reaction [10-12,18,19,23-28], immunostaining for EBV-encoded nuclear antigen 1/2 [10,12-14,25,26], or in situ hybridization for small EBV-encoded RNAs [12,15-17]. EBV positive breast tumors are less frequent in the United States (0-25\%) [12,15,16], Mexico (0-5\%) [28], Germany (7\%) [13], and Iran (0\%) [26], compared to Argentina (35\%) [23], United Kingdom (21\%) [9,10], France (2751\%) [18,29], The Netherlands (33\%) [29], Denmark (35\%) [29], Portugal (25\%) [24], Algeria (40\%) [29], Tunisia (27-33\%) [29,30], Eritrea (28-36\%) [19], Egypt (45\%) [31], Iraq (28\%) [31], Lebanon (40\%) [25], India (30-55\%) [14,17], Pakistan (24\%) [27], and 
medRxiv preprint doi: https://doi.org/10.1101/2021.10.05.21264564; this version posted October 7, 2021. The copyright holder for this preprint (which was not certified by peer review) is the author/funder, who has granted medRxiv a license to display the preprint in perpetuity. All rights reserved. No reuse allowed without permission.

China (60\%) [11]. However, three meta-analyses conducted using these histopathologybased studies listed above concluded that EBV increases breast cancer risk [32-34].

The life-long association of EBV in a large population of people makes it challenging to clarify a causal link between this virus and breast cancer [35]. When IM is used as a surrogate for latent EBV infection, epidemiological investigations do not support an association between EBV infection and breast cancer risk [36-38]. For example, we previously reported no association between IM and breast cancer risk using data from the Nurses' Health Study II, a prospective study of $>100,000$ young female nurses in the United States [37]. Further investigations into the association between IM and breast cancer risk is warranted in order to understand whether IM may be a breast cancer risk factor, as well as inform the usefulness of an EBV vaccine as a breast cancer prevention tool. In this current study, we utilized The Health of Women (HOW) Study® to further explore the association between IM and breast cancer risk.

\section{Materials and methods}

\section{Study Population}

The HOW Study® (NCT02334085) was a collection of cross-sectional, web-based surveys of breast cancer risk factors completed by participants aged 18 or older with and without breast cancer [39]. Most participants were residing in the United States at the time of survey $(<1 \%$ international responses) [39]. The HOW Study® consisted of seven modules released sequentially from 2012-2015: 1) My Health Overview, 2) My 
medRxiv preprint doi: https://doi.org/10.1101/2021.10.05.21264564; this version posted October 7, 2021. The copyright holder for this preprint (which was not certified by peer review) is the author/funder, who has granted medRxiv a license to display the preprint in perpetuity. All rights reserved. No reuse allowed without permission.

Breast Cancer, 3) My Personal and Family Health History, 4) Health, Weight, and Exercise, 5) Environmental Exposure, 6) Quality of Life, and 7) Bacteria in the Breast. These modules assessed health histories (general, reproductive, and family), lifestyle factors, environmental exposures, breast cancer diagnosis and treatment, and cancer survivorship life quality. Survey enrollment closed in 2019; data in this manuscript were from the 2016 data freeze. Participants provided written consent. The HOW Study® protocol was approved by the Western Institutional Review Board.

\section{Ascertainment of IM}

My Health Overview collected information related to socio-demographics, current health status and behaviors, reproductive history, and data on health-limiting activities. It was completed by 42,540 participants with $13,285(31.2 \%)$ indicating they had breast cancer [39]. A subset of female participants between the ages 18 and 91 also completed My Personal and Family Health History ( $n=22,355$ out of 42,540; 52.6\%). These women identified as cisgender female on both modules. My Personal and Family Health History collected information about genetic risk factors or predispositions for breast cancer, including whether they had IM (yes/no; $n=21,701$ ). Women were excluded if they indicated "don't know" or if they did not answer the question ( $n=654 ; 2.9 \%)$.

If the woman answered "yes", they were asked for their age at the time of IM diagnosis ( $<10$ years old, 10-22 years old, $>22$ years old, or unknown) and how IM was diagnosed (by physician based on symptoms, laboratory blood test, lymph node biopsy, or unknown). We focused on women who had IM between 10 and 22 years old $(n=3,654 ; 16.8 \%)$ and those who indicated they never developed IM $(n=17,026 ; 78.5 \%)$. 
medRxiv preprint doi: https://doi.org/10.1101/2021.10.05.21264564; this version posted October 7, 2021. The copyright holder for this preprint (which was not certified by peer review) is the author/funder, who has granted medRxiv a license to display the preprint in perpetuity. All rights reserved. No reuse allowed without permission.

Women who had IM at $<10$ years old $(n=183 ; 0.8 \%)$, $>22$ years old $(n=764 ; 3.5 \%)$, or unknown age $(n=74 ; 0.3 \%)$ were excluded from this study due to insufficient power.

\section{Ascertainment of primary breast cancer}

The ascertainment of first primary breast cancer and age at diagnosis were derived from My Health Overview, My Breast Cancer, Quality of Life, and Bacteria in the Breast. Of the remaining 20,680 women who either had IM between the ages of 10 and 22 or never developed IM, 1,997 (9.7\%) had Stages I-III breast cancer and 13,515 (65.4\%) were breast cancer-free. We excluded 1,398 (6.8\%) who self-reported in situ breast cancer, $45(0.2 \%)$ with Stage IV, 3,707 (17.9\%) who had breast cancer but it was unclear whether the cancer was in situ or invasive, and $18(0.1 \%)$ with unknown breast cancer status. Age at invasive breast cancer diagnosis was grouped into 20-24, 25-29, $30-34,35-39,40-44,45-49,50-54,55-59,60-64,65-69,70-74,75-79$, and $\geq 80$ years old. No breast cancer case occurred before the onset of IM.

\section{Statistical analysis}

We determined whether IM was associated with later development of invasive breast cancer by using multivariable binary logistic regression to calculate odds ratios (ORs) and $95 \%$ confidence intervals (Cls). The HOW Study ${ }^{\circledR}$ modules did not specifically collect epidemiological data closest to or at time of breast cancer diagnosis. In model 1 , we controlled for potential confounding of these variables that were likely to be similar at time of breast cancer diagnosis and at the time of the survey: ethnicity (white versus others), family history of female breast cancer (yes/no), age at menarche $(<10,10,11$, $12,13,14,15,16$, or $\geq 17$ years old), use of oral contraceptives (ever/never), any 
tobacco (ever/never), and birthplace (United States/Canada versus foreign born). We decided to include birthplace because subclinical EBV infection may be acquired in childhood.

For model 2, we controlled for variables in model 1 as well as these additional variables obtained at time of survey that may not accurately reflect the status at time of breast cancer diagnosis: parity (nulliparous, primiparous, multiparous, or unknown), age at first birth $(<18,18-24,25-29,30-34,35-39,40-44$, or $\geq 45)$, BMl $\left(\mathrm{kg} / \mathrm{m}^{2}\right)$, and had a breast biopsy (ever/never). These variables were extracted from My Health Overview and My Personal and Family Health History. We conducted sensitivity analyses by restricting to women born in the United States or Canada as well as women diagnosed with IM using a laboratory blood test. Finally, we conducted secondary analyses by stratifying cancer cases into those who had breast cancer at $<50$ or $\geq 50$ years old; and by estrogen receptor (ER) status. We were unable to evaluate menopausal status at time of first primary breast cancer $(>66.7 \%$ missing data) or at time of survey $(>40 \%$ missing data).

\section{Results}

Our study participants consisted of 2,773 (17.9\%) women who had IM between the ages of 10 and 22 and $12,739(82.1 \%)$ who did not have IM. The majority of women who had IM were diagnosed with a laboratory blood test (53.1\%; Table 1). Our women were mostly white, middle-aged, and born in the United States or Canada (Table 1). 
Among the 80 women who had IM and were not born in the United States or Canada, $63(78.8 \%)$ indicated they have been living in the United States for $>10$ years, $1(1.2 \%)$ woman has been living in the United States between 4 to 7 years, and $16(20.0 \%)$ did not answer. The variables of interest were similar between those who had IM and did not develop IM (Table 1). Most women had a family history of female breast cancer ( $>50 \%)$, never had a breast biopsy, started menstruating around 12 years old, were multiparous, had normal BMI, used oral contraceptives, but were less likely to use tobacco. Women who had IM were more likely to have breast fed for at least 12 months.

Among those diagnosed with breast cancer, the most common age category at diagnosis was between 50 and 59 (Table 2). The majority of the breast cancers were of stages I and II (85.5\%); 68.8\% were ER positive and 43.7\% were progesterone receptor positive (Table 2).

Women who had IM between the ages of 10 and 22 were less likely to develop breast cancer than those who did not develop IM after controlling for ethnicity, family history, age at menarche, oral contraceptive use, tobacco use, and birthplace (adjusted $\mathrm{OR}=0.82,95 \% \mathrm{Cl}$ 0.72-0.93; Model 1). This association remained significant after additionally controlling for parity, age at first birth, BMI, and breast biopsy (adjusted $\mathrm{OR}=0.83,95 \% \mathrm{Cl}$ 0.71-0.96; Model 2; Table 3A1). Our findings were unaltered when restricted to women born in the United States/Canada (Model 2: adjusted OR= 0.82 , 95\% Cl 0.71-0.96; Table 3A2). When comparing women whose IM was diagnosed using a laboratory blood test versus those who did not develop IM, the findings were 
similar for Model 1 (adjusted OR=0.79, 95\% $\mathrm{Cl} 0.67-0.94$ ) but was attenuated in Model 2 (adjusted OR= 0.88, 95\% Cl 0.72-1.07; Table 3A3).

The risk of developing invasive breast cancer by age of 50 was slightly lower in women who had IM versus those who did not develop IM (Model 2: adjusted OR=0.82, 95\% $\mathrm{Cl}$ 0.67-0.998; Table 3B1). Similar results were observed regarding the risk of developing invasive breast cancer after 50 years old between women who had IM versus those that did not develop IM (Model 2: adjusted OR=0.83, 95\% Cl 0.69-1.00; Table 3B2). When stratified by ER status, women who had IM were less likely to develop ER positive breast cancer compared to those who did not develop IM (Model 2: adjusted $\mathrm{OR}=0.84,95 \% \mathrm{Cl} 0.71-0.997$; Table $3 \mathrm{C} 1$ ). There was no association between IM and ER negative breast cancer (Model 2: adjusted OR=0.88, 95\% $\mathrm{Cl}$ 0.65-1.16; Table 3C2). 


\section{Discussion}

The link between EBV and breast cancer is controversial. The role of IM in the etiology of breast cancer remains unclear. Meta-analyses indicate that EBV is associated with increased breast cancer risk [32-34]. However, the studies included in the metaanalyses were not designed to elucidate whether EBV infection plays a role in the etiology of breast cancer. Population-based studies concluded null associations between IM and breast cancer [36-38]. We previously reported that ex vivo EBV infection of primary mammary epithelial cells, but not of established cancer cells, can lead to transcriptional re-programming and malignant transformation in organoid assays as well as to formation of breast cancers in a mouse model [20]. Therefore, we specifically designed this study using data from the HOW Study® to address whether the developing IM at the time of adolescent breast development when the population of mammary epithelial cells is expanding had an impact on later breast cancer

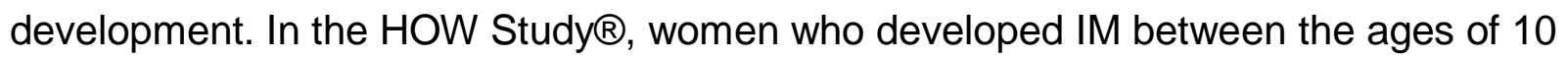
and 22 had a lower risk of developing breast cancer, particularly ER positive subtype, than those who did not develop IM. Our findings when taken together with previous population-based studies [36-38] suggest that an EBV vaccine is unlikely have an impact on reducing breast cancer risk.

There are several potential explanations for the discordance between pre-clinical studies $[20,21]$ and the findings of this study: (1) The HOW Study® data did not allow us to address whether EBV infection at any age, including early childhood and asymptomatic exposures, modulates BC risk; (2) Most of the HOW Study® participants were white women. Thus, this study had insufficient power to address risk in women of 
African and South-East Asian descent, i.e. women from geographical areas where EBVassociated malignancies, triple-negative breast cancer, and early-onset breast cancer are more prevalent; (3) It is possible that EBV infection in humans does not result in effective infection of mammary epithelial cells even though EBV has been found to be excreted with breast milk [40]; and (4) It is also possible that EBV infected human mammary epithelial cells are effectively cleared by the immune system.

Previous population-based studies concluded a lack of association between IM and breast cancer [36-38]. The discordant findings between those studies and ours may be attributed to the difference in rate of IM cases. The demographics of the Nurses' Health Studies is similar to the HOW Study ${ }^{\circledR} —$ college educated, white females born or residing in the United States and Canada-however the number of women diagnosed with IM between ages $\leq 15$ to $24(15.2 \%)$ in the Nurses' Health Studies [37] was lower than our study (17.9\%). Similarly, the rate of IM in Yasui et al was also lower than our study (31 had IM between ages 10 and 24 versus 972 never had IM; 3.2\%) possibly due to their unique female population recruited in King County, Washington, United States. The IM rate among Swedish and Danish females in the study by Hjalgrim et al [38] was not reported. Nevertheless, our findings remained robust when restricted to laboratoryconfirmed IM diagnosis. Age at breast cancer ( $<50$ or $\geq 50$ years old) also did not alter the results.

The strengths of our study include investigating the association of IM and breast cancer in a newly established, large research population. The HOW Study® collected exposure information about IM (age and method of diagnosis) and breast cancer risk 
factors. Limitations of our study include self-reported IM and self-reported method of IM diagnosis. We were unable to control for menopausal status, BMI, and alcohol intake at time of breast cancer diagnosis because those exposures were not specifically asked in the surveys. We made an effort to control for BMI at time of survey in our multivariable Model 2. The high degree of similarity between Models 1 and 2 presented in Table 3 confirms there is minimal confounding for the association between IM and breast cancer [37].

\section{Conclusion}

Women in the HOW Study® who had IM between the ages of 10 and 22 were less likely to develop breast cancer, particularly of the ER positive subtype, compared to women who never developed IM. Our data do not support the development of an EBV vaccine for breast cancer prevention in the United States or Canada. 


\section{Declarations}

\section{Ethics approval and consent to participate}

The Health of Women (HOW) Study® protocol was approved by the Western Institutional Review Board. Participants provided written consent.

\section{Consent for publication}

Not applicable.

\section{Availability of data and materials}

The Health of Women (HOW) Study ${ }^{\circledR}$ data that support the findings of this study are available from Dr. Susan Love Research Foundation but restrictions apply to the availability of these data, which were used under license for the current study, and so are not publicly available. Data access and policy details can be accessed at https://loveresearcharmy.org/researchers/faqs.

\section{Competing interests}

All authors have no conflict of interest to disclose.

\section{Funding}

GMW is supported by the AVON Foundation, the Breast Cancer Research Foundation, and the Ludwig Center at Harvard Medical School.

\section{Authors' contributions}

Yujing J Heng: Formal analysis, writing - review and editing; Susan Love: Resources, writing - review and editing; Jessica Clague DeHart: Data curation, writing - review and editing; Joyce D. Fingeroth: Conceptualization, writing - review and editing; Gerburg M. Wulf: Conceptualization, writing - review and editing 
medRxiv preprint doi: https://doi.org/10.1101/2021.10.05.21264564; this version posted October 7, 2021. The copyright holder for this preprint (which was not certified by peer review) is the author/funder, who has granted medRxiv a license to display the preprint in perpetuity. All rights reserved. No reuse allowed without permission.

\section{Acknowledgements}

We thank the staff and participants of the HOW Study ${ }^{\circledR}$ and the Dr. Susan Love Research Foundation for providing this dataset. We thank Leah Eshraghi and Katherine M. Peterson for reading this manuscript. The authors assume full responsibility for analyses and interpretation of these data. 
medRxiv preprint doi: https://doi.org/10.1101/2021.10.05.21264564; this version posted October 7, 2021. The copyright holder for this preprint (which was not certified by peer review) is the author/funder, who has granted medRxiv a license to display the preprint in perpetuity. All rights reserved. No reuse allowed without permission.

\section{References}

1. Cohen JI. Epstein-Barr virus infection. N Engl J Med. United States; 2000;343:48192.

2. Evans A. The spectrum of infections with epstein-barr virus: A hypothesis. J. Infect. Dis. 1971. p. 330-7.

3. Kapatai G, Murray P. Contribution of the Epstein-Barr virus to the molecular pathogenesis of Hodgkin lymphoma. J Clin Pathol. 2007;60:1342-9.

4. Epstein MA, Barr YM. Cultivation in Vitro of Human Lymphoblasts From Burkitt's Malignant Lymphoma. Lancet. 1964;283:252-3.

5. Bass AJ, Thorsson V, Shmulevich I, Reynolds SM, Miller M, Bernard B, et al. Comprehensive molecular characterization of gastric adenocarcinoma. Nature. 2014;513:202-9.

6. Wolf $\mathrm{H}$, zur Hausen $\mathrm{H}$, Klein G, Becker V, Henle G, Henle W. Attempts to detect virus-specific DNA sequences in human tumors - III. Epstein-Barr viral DNA in nonlymphoid nasopharyngeal carcinoma cells. Med Microbiol Immunol. 1975;161:15-21.

7. Cohen JI, Fauci AS, Varmus H, Nabel GJ. Epstein-Barr virus: An important vaccine target for cancer prevention. Sci Transl Med. 2011;3:107fs7.

8. Khan G, Fitzmaurice C, Naghavi M, Ahmed LA. Global and regional incidence, mortality and disability-adjusted life-years for Epstein-Barr virus-attributable malignancies, 1990-2017. BMJ Open. 2020;10:e037505.

9. Labrecque LG, Barnes DM, Fentiman IS, Griffin BE. Epstein-Barr Virus in Epithelial Cell Tumors: A Breast Cancer Study. Cancer Res. 1995;55:39-45.

10. Murray PG, Lissauer D, Junying J, Davies G, Moore S, Bell A, et al. Reactivity with a monoclonal antibody to Epstein-Barr virus (EBV) nuclear antigen 1 defines a subset of aggressive breast cancers in the absence of the EBV genome. Cancer Res. 2003;63:2338-43.

11. Peng J, Wang T, Zhu H, Guo J, Li K, Yao Q, et al. Multiplex PCR/mass spectrometry screening of biological carcinogenic agents in human mammary tumors. $J$ Clin Virol. 2014;61:255-9.

12. Chu PG, Chang KL, Chen YY, Chen WG, Weiss LM. No significant association of Epstein-Barr virus infection with invasive breast carcinoma. Am J Pathol. 2001;159:571-8.

13. Herrmann K, Niedobitek G. Lack of evidence for an association of Epstein-Barr virus infection with breast carcinoma. Breast Cancer Res. 2002;5:R13.

14. Joshi D, Quadri M, Gangane N, Joshi R, Gangane N. Association of epstein barr virus infection (ebv) with breast cancer in rural indian women. PLoS One. 2009;4:e8180. 
medRxiv preprint doi: https://doi.org/10.1101/2021.10.05.21264564; this version posted October 7, 2021. The copyright holder for this preprint (which was not certified by peer review) is the author/funder, who has granted medRxiv a license to display the preprint in perpetuity. All rights reserved. No reuse allowed without permission.

15. Glashr SL, Ambinder RF, Digiuseppe JA, Horn-Ross PL, Hsu JL. Absence of Epstein-Barr virus EBER-1 transcripts in an epidemiologically diverse group of breast cancers. Int J Cancer. 1998;75:555-8.

16. Deshpande CG, Badve S, Kidwai N, Longnecker R. Lack of expression of the epstein-barr virus (ebv) gene products, ebers, ebna1, Imp1, and Imp2a, in breast cancer cells. Lab Investig. 2002;82:1193-9.

17. Pai T, Gupta S, Gurav M, Nag S, Shet T, Patil A, et al. Evidence for the association of Epstein-Barr Virus in breast cancer in Indian patients using in-situ hybridization technique. Breast J. 2018;24:16-22.

18. Bonnet M, Guinebretiere JM, Kremmer E, Grunewald V, Benhamou E, Contesso G, et al. Detection of Epstein-Barr virus in invasive breast cancers. J Natl Cancer Inst. 1999;91:1376-81.

19. Fessahaye G, Elhassan AM, Elamin EM, Adam AAM, Ghebremedhin A, Ibrahim ME. Association of Epstein - Barr virus and breast cancer in Eritrea. Infect Agent Cancer. 2017;12:62.

20. Hu H, Luo ML, Desmedt C, Nabavi S, Yadegarynia S, Hong A, et al. Epstein-Barr Virus Infection of Mammary Epithelial Cells Promotes Malignant Transformation. EBioMedicine. 2016; 9:148-60.

21. Arbach H, Viglasky V, Lefeu F, Guinebretière J-M, Ramirez V, Bride N, et al. Epstein-Barr Virus (EBV) Genome and Expression in Breast Cancer Tissue: Effect of EBV Infection of Breast Cancer Cells on Resistance to Paclitaxel (Taxol). J Virol. 2006;80:845-53.

22. Mostafaei S, Vahidi Manesh P, Sadri Nahand J, Nesaei A, Sorayyayi S, Abasabadi $\mathrm{F}$, et al. The role of Epstein-Barr virus-expressed genes in breast cancer development. Breast J. 2020;26:2323-6.

23. Preciado MV, Chabay PA, De Matteo EN, Gonzalez P, Grinstein S, Actis A, et al. Epstein-Barr virus in breast carcinoma in Argentina. Arch Pathol Lab Med. 2005;129:377-81.

24. Marrão G, Habib M, Paiva A, Bicout D, Fallecker C, Franco S, et al. Epstein-Barr virus infection and clinical outcome in breast cancer patients correlate with immune cell TNF-a/IFN-y response. BMC Cancer. 2014;14:665.

25. Nagi K, Gupta I, Jurdi N, Jabeen A, Yasmeen A, Batist G, et al. High-risk human papillomaviruses and Epstein-Barr virus in breast cancer in Lebanese women and their association with tumor grade: a molecular and tissue microarray study. Cancer Cell Int. $2021 ; 21$.

26. Kadivar M, Monabati A, Joulaee A, Hosseini N. Epstein-Barr virus and breast cancer: Lack of evidence for an association in Iranian women. Pathol Oncol Res. 2011;17:489-92. 
medRxiv preprint doi: https://doi.org/10.1101/2021.10.05.21264564; this version posted October 7, 2021. The copyright holder for this preprint (which was not certified by peer review) is the author/funder, who has granted medRxiv a license to display the preprint in perpetuity. All rights reserved. No reuse allowed without permission.

27. Naushad W, Surriya O, Sadia H. Prevalence of EBV, HPV and MMTV in Pakistani breast cancer patients: A possible etiological role of viruses in breast cancer. Infect Genet Evol. 2017;54:230-7.

28. Morales-Sánchez A, Molina-Muñoz T, Martínez-López JLE, Hernández-Sancén P, Mantilla A, Leal YA, et al. No association between Epstein-Barr Virus and Mouse Mammary Tumor Virus with Breast Cancer in Mexican Women. Sci Rep. 2013;3:2970.

29. Fina F, Romain S, Ouafik L, Palmari J, Ayed F Ben, Benharkat S, et al. Frequency and genome load of Epstein-Barr virus in 509 breast cancers from different geographical areas. Br J Cancer. 2001;84:783-90.

30. Hachana M, Amara K, Ziadi S, Romdhane E, Gacem R Ben, Trimeche M. Investigation of Epstein-Barr virus in breast carcinomas in Tunisia. Pathol Res Pract. $2011 ; 207: 695-700$.

31. Zekri ARN, Bahnassy AA, Mohamed WS, El-Kassem FA, El-Khalidi SJ, Hafez MM, et al. Epstein-Barr virus and breast cancer: Epidemiological and Molecular study on Egyptian and Iraqi women. J Egypt Natl Canc Inst. 2012;24:123-31.

32. Huo Q, Zhang N, Yang Q. Epstein-barr virus infection and sporadic breast cancer risk: A meta-analysis. PLoS One. 2012. p. e31656.

33. Farahmand M, Monavari SH, Shoja Z, Ghaffari H, Tavakoli M, Tavakoli A. EpsteinBarr virus and risk of breast cancer: A systematic review and meta-analysis. Futur Oncol. 2019;15:2873-85.

34. Jin Q, Su J, Yan D, Wu S. Epstein-Barr Virus Infection and Increased Sporadic Breast Carcinoma Risk: A Meta-Analysis. Med Princ Pract. 2020;29:195-200.

35. Sinclair AJ, Moalwi MH, Amoaten T. Is ebv associated with breast cancer in specific geographic locations? Cancers (Basel). 2021;13:1-8.

36. Yasui Y, Potter JD, Stanford JL, Rossing MA, Winget MD, Bronner M, et al. Breast cancer risk and "delayed" primary Epstein-Barr virus infection. Cancer Epidemiol Biomarkers Prev. 2001;10:9-16.

37. Massa J, Hamdan A, Simon KC, Bertrand K, Wulf G, Tamimi RM, et al. Infectious mononucleosis and risk of breast cancer in a prospective study of women. Cancer Causes Control. 2012;23:1893-8.

38. Hjalgrim H, Askling J, Sørensen P, Madsen M, Rosdahl N, Storm HH, et al. Risk of Hodgkin's disease and other cancers after infectious mononucleosis. J Natl Cancer Inst. 2000;92:1522-8.

39. Guida J., Green P, Clague DeHart J, Eshraghi L, Laurita N, O'Connell M, et al. The Health of Women (HOW) Study®: A Web-Based Survey of Breast Cancer Risk Factors, Diagnosis, and Treatment. Press.

40. Montoya-Ferrer A, Sanosyan A, Fayd'Herbe De Maudave A, Pisoni A, Bollore K, 
medRxiv preprint doi: https://doi.org/10.1101/2021.10.05.21264564; this version posted October 7, 2021. The copyright holder for this preprint (which was not certified by peer review) is the author/funder, who has granted medRxiv a license to display the preprint in perpetuity. All rights reserved. No reuse allowed without permission.

Molès JP, et al. Clinical and Biological Factors Associated with Early Epstein-Barr Virus Infection in Human Immunodeficiency Virus-Exposed Uninfected Infants in Eastern Uganda. Clin Infect Dis. 2021;72:1026-32. 
medRxiv preprint doi: https://doi.org/10.1101/2021.10.05.21264564; this version posted October 7, 2021. The copyright holder for this preprint (which was not certified by peer review) is the author/funder, who has granted medRxiv a license to display the preprint in perpetuity. All rights reserved. No reuse allowed without permission.

Table 1. Demographic and breast cancer risk factors of study participants who had infectious mononucleosis (IM) between ages 10 and 22 and those who never developed IM.

\begin{tabular}{|c|c|c|}
\hline & Had IM & Never developed IM \\
\hline $\mathrm{n}$ & 2773 & 12739 \\
\hline How IM was diagnosed, n (\%) & & - \\
\hline By a physician based on symptoms & $512(18.5)$ & - \\
\hline Laboratory blood test & $1473(53.1)$ & - \\
\hline Lymph node biopsy & $2(0.1)$ & - \\
\hline Unknown & $786(28.3)$ & - \\
\hline Age at My Health Overview survey, median [IQR] & $52.0[40.0,61.0]$ & $54.0[42.0,62.0]$ \\
\hline \multicolumn{3}{|l|}{ Birthplace, n (\%) } \\
\hline United States/Canada & $2693(97.1)$ & $12145(95.3)$ \\
\hline Western Europe/United Kingdom/Scandinavia & $45(1.6)$ & $283(2.2)$ \\
\hline Australia/New Zealand & $9(0.3)$ & $51(0.4)$ \\
\hline Mexico/Central America/South America & $5(0.2)$ & $67(0.5)$ \\
\hline Asia & $5(0.2)$ & $69(0.5)$ \\
\hline Middle East/Israel & $3(0.1)$ & $13(0.1)$ \\
\hline Eastern Europe/Soviet Union & $1(0.0)$ & $25(0.2)$ \\
\hline Pacific Islands & $1(0.0)$ & $9(0.1)$ \\
\hline Africa & $1(0.0)$ & $20(0.2)$ \\
\hline Unknown & $10(0.4)$ & $57(0.4)$ \\
\hline \multicolumn{3}{|l|}{ Ethnicity, n (\%) } \\
\hline White & 2641 (95.2) & $11670(91.6)$ \\
\hline Black & $10(0.4)$ & $175(1.4)$ \\
\hline Mixed Race & $105(3.8)$ & $717(5.6)$ \\
\hline Asian & $5(0.2)$ & $114(0.9)$ \\
\hline Others & $11(0.4)$ & $40(0.3)$ \\
\hline Unknown & $1(0.0)$ & $23(0.2)$ \\
\hline \multicolumn{3}{|l|}{ Family history of female breast cancer, $\mathrm{n}(\%)$} \\
\hline First degree members & $403(14.5)$ & $2117(16.6)$ \\
\hline Second degree members & $746(26.9)$ & $3057(24.0)$ \\
\hline Both first and second degree members & $412(14.9)$ & $1753(13.8)$ \\
\hline None & $1001(36.1)$ & $4674(36.7)$ \\
\hline Unknown & $211(7.6)$ & $1138(8.9)$ \\
\hline \multicolumn{3}{|l|}{ Had a previous breast biopsy, $n(\%)^{*}$} \\
\hline Yes, diagnosed with atypia lesions & $96(3.5)$ & $502(3.9)$ \\
\hline Yes, diagnosed with non-atypia lesions & $696(25.1)$ & $3452(27.1)$ \\
\hline Yes, unknown results & $167(6.0)$ & $636(5.0)$ \\
\hline Never & $1811(65.3)$ & $8139(63.9)$ \\
\hline Unknown & $3(0.1)$ & $10(0.1)$ \\
\hline \multicolumn{3}{|l|}{ Reproductive Factors } \\
\hline \multicolumn{3}{|l|}{ Age at menarche, $\mathrm{n}(\%)$} \\
\hline$\leq 11$ years old & $626(22.6)$ & $2730(21.4)$ \\
\hline 12 years old & $785(28.3)$ & $3778(29.7)$ \\
\hline 13 years old & $727(26.2)$ & $3318(26.0)$ \\
\hline$\geq 14$ years old & $543(19.6)$ & 2458 (19.3) \\
\hline Unknown & $92(3.3)$ & $455(3.6)$ \\
\hline \multicolumn{3}{|l|}{ Parity, n (\%)* } \\
\hline Nulliparous & $720(26.0)$ & $3413(26.8)$ \\
\hline Primiparous & $459(16.6)$ & 2078 (16.3) \\
\hline Multiparous & $1260(45.4)$ & $5794(45.5)$ \\
\hline Unknown & $334(12.0)$ & $1454(11.4)$ \\
\hline Age at first birth among parous women, $\mathrm{n}(\%)^{*}$ & & \\
\hline
\end{tabular}


medRxiv preprint doi: https://doi.org/10.1101/2021.10.05.21264564; this version posted October 7, 2021. The copyright holder for this preprint (which was not certified by peer review) is the author/funder, who has granted medRxiv a license to display the preprint in perpetuity. All rights reserved. No reuse allowed without permission.

\begin{tabular}{|c|c|c|}
\hline$<18$ years old & $52(3.0)$ & $273(3.5)$ \\
\hline $18-24$ years old & $557(32.4)$ & $2867(36.4)$ \\
\hline $25-29$ years old & $637(37.1)$ & $2766(35.1)$ \\
\hline 30-34 years old & $364(21.2)$ & $1464(18.6)$ \\
\hline $35-39$ years old & $93(5.4)$ & $424(5.4)$ \\
\hline 40-44 years old & $12(0.7)$ & $68(0.9)$ \\
\hline$\geq 45$ years old & $1(0.1)$ & $3(0.0)$ \\
\hline Unknown & $3(0.2)$ & $7(0.1)$ \\
\hline \multicolumn{3}{|l|}{ Total length of breastfeeding among parous women, $\mathrm{n}(\%)^{*}$} \\
\hline$<12$ months & 743 (43.2) & $3774(47.9)$ \\
\hline$\geq 12$ months & $903(52.5)$ & $3780(48.0)$ \\
\hline Unknown & $73(4.2)$ & $318(4.0)$ \\
\hline \multicolumn{3}{|l|}{ Modifiable Factors } \\
\hline Body Mass Index, median [IQR]* & $24.7[22.0,29.0]$ & $25.0[22.1,29.1]$ \\
\hline \multicolumn{3}{|l|}{ Oral contraceptive use, $\mathrm{n}(\%)$} \\
\hline Ever & $2469(89.0)$ & $10927(85.8)$ \\
\hline Never & $304(11.0)$ & $1803(14.2)$ \\
\hline Unknown & $0(0.0)$ & $9(0.1)$ \\
\hline \multicolumn{3}{|l|}{ Tobacco use, $\mathrm{n}(\%)$} \\
\hline Ever & $1166(42.0)$ & 5119 (40.2) \\
\hline Never & $1600(57.7)$ & $7591(59.6)$ \\
\hline Unknown & $7(0.3)$ & $29(0.2)$ \\
\hline
\end{tabular}

*These variables were collected at time of answering My Health Overview or My Personal and Family Health History surveys and may not accurately reflect the status at time of breast cancer diagnosis.

Percentages may not sum to 100 due to rounding. Interquartile range, IQR. 
medRxiv preprint doi: https://doi.org/10.1101/2021.10.05.21264564; this version posted October 7, 2021. The copyright holder for this preprint (which was not certified by peer review) is the author/funder, who has granted medRxiv a license to display the preprint in perpetuity. All rights reserved. No reuse allowed without permission.

Table 2. Breast cancer characteristics of study participants who had infectious mononucleosis (IM) between ages 10 and 22 and those who never developed IM.

\begin{tabular}{|c|c|c|}
\hline & Had IM & Never developed IM \\
\hline & 2773 & 12739 \\
\hline \multicolumn{3}{|l|}{ Breast cancer, $\mathrm{n}(\%)$} \\
\hline Yes & $311(11.2)$ & 1686 (13.2) \\
\hline No & $2462(88.8)$ & $11053(86.8)$ \\
\hline \multicolumn{3}{|l|}{ Among breast cancer cases } \\
\hline \multicolumn{3}{|l|}{ Age at diagnosis, $\mathrm{n}(\%)$} \\
\hline$<40$ years old & $52(16.7)$ & $248(14.7)$ \\
\hline 40-49 years old & $95(30.5)$ & 546 (32.4) \\
\hline 50-59 years old & $111(35.7)$ & $590(35.0)$ \\
\hline 60-69 years old & $47(15.1)$ & $266(15.8)$ \\
\hline$\geq 70$ years old & $6(1.9)$ & $36(2.1)$ \\
\hline \multicolumn{3}{|l|}{ Stage, n (\%) } \\
\hline Stage I & $130(41.8)$ & $743(44.1)$ \\
\hline Stage II & $131(42.1)$ & 704 (41.8) \\
\hline Stage III & $50(16.1)$ & $239(14.2)$ \\
\hline \multicolumn{3}{|l|}{ Estrogen receptor status, $\mathrm{n}(\%)$} \\
\hline Positive & $215(69.1)$ & 1159 (68.7) \\
\hline Negative & $62(19.9)$ & $312(18.5)$ \\
\hline Unknown & $34(10.9)$ & $215(12.8)$ \\
\hline \multicolumn{3}{|l|}{ Progesterone receptor status, n (\%) } \\
\hline Positive & 149 (47.9) & 723 (42.9) \\
\hline Negative & $91(29.3)$ & $523(31.0)$ \\
\hline Unknown & $71(22.8)$ & $440(26.1)$ \\
\hline
\end{tabular}

Percentages may not sum to 100 due to rounding. 
medRxiv preprint doi: https://doi.org/10.1101/2021.10.05.21264564; this version posted October 7, 2021. The copyright holder for this preprint (which was not certified by peer review) is the author/funder, who has granted medRxiv a license to display the preprint in perpetuity.

All rights reserved. No reuse allowed without permission.

Table 3. Association of infectious mononucleosis (IM) between ages 10 and 22 and breast cancer using logistic regression models to estimate odds ratios (ORs) and 95\% confidence intervals (Cls).

\begin{tabular}{|c|c|}
\hline \multicolumn{2}{|l|}{ A1. IM and breast cancer } \\
\hline Cases (IM yes/no) / Controls (IM yes/no), $\mathrm{n}$ & $(311 / 2462) /(1686 / 11053)$ \\
\hline Crude & $0.83(0.73-0.94)$ \\
\hline Model 1 & $0.82(0.72-0.93)$ \\
\hline Model 2 & $0.83(0.71-0.96)$ \\
\hline \multicolumn{2}{|l|}{$\begin{array}{l}\text { A2. IM and breast cancer among women born in the United } \\
\text { States/Canada }\end{array}$} \\
\hline Cases (IM yes/no) / Controls (IM yes/no), $\mathrm{n}$ & $(297 / 1595) /(2396 / 10550)$ \\
\hline Crude & $0.82(0.72-0.93)$ \\
\hline Model 1 & $0.81(0.71-0.92)$ \\
\hline Model 2 & $0.82(0.71-0.96)$ \\
\hline \multicolumn{2}{|l|}{$\begin{array}{l}\text { A3. IM and breast cancer among women whose IM were diagnosed by a } \\
\text { laboratory blood test }\end{array}$} \\
\hline Cases (IM yes/no) / Controls (IM yes/no), n & $(160 / 1686) /(1313 / 11053)$ \\
\hline Crude & $0.80(0.67-0.95)$ \\
\hline Model 1 & $0.79(0.67-0.94)$ \\
\hline Model 2 & $0.88(0.72-1.07)$ \\
\hline \multicolumn{2}{|l|}{ B1. IM and breast cancer at $<50$ years old } \\
\hline Cases (IM yes/no) / Controls (IM yes/no), n & $(147 / 794) /(2462 / 11053)$ \\
\hline Crude & $0.83(0.69-0.99)$ \\
\hline Model 1 & $0.83(0.69-0.99)$ \\
\hline Model 2 & $0.82(0.67-0.998)$ \\
\hline \multicolumn{2}{|l|}{ B2. IM and breast cancer at $>50$ years old } \\
\hline Cases (IM yes/no) / Controls (IM yes/no), n & $(164 / 892) /(2462 / 11053)$ \\
\hline Crude & $0.83(0.69-0.98)$ \\
\hline Model 1 & $0.82(0.69-0.97)$ \\
\hline Model 2 & $0.83(0.69-1.00)$ \\
\hline \multicolumn{2}{|l|}{ C1. IM and estrogen receptor positive breast cancer } \\
\hline Cases (IM yes/no) / Controls (IM yes/no), $\mathrm{n}$ & $(215 / 1159) /(2462 / 11053)$ \\
\hline Crude & $0.83(0.71-0.97)$ \\
\hline Model 1 & $0.83(0.71-0.97)$ \\
\hline Model 2 & $0.84(0.71-0.997)$ \\
\hline \multicolumn{2}{|l|}{ C2. IM and estrogen receptor negative breast cancer } \\
\hline Cases (IM yes/no) / Controls (IM yes/no), $\mathrm{n}$ & $(62 / 312) /(2462 / 11053)$ \\
\hline Crude & $0.89(0.67-1.17)$ \\
\hline Model 1 & $0.87(0.65-1.14)$ \\
\hline Model 2 & $0.88(0.65-1.16)$ \\
\hline
\end{tabular}

Model 1 adjusted for ethnicity, family history, age at menarche, oral contraceptive use, tobacco use, and birthplace. Model 2 adjusted for the co-variables in Model 1 as well as parity, age at first birth, BMI, and breast biopsy. 